\title{
The development of the reproductive organs of the male giraffe, Giraffa camelopardalis
}

\author{
A. J. Hall-Martin*, J. D. Skinner* and B. J. Hopkins $\dagger$ \\ *Mammal Research Institute and $\uparrow$ Institute of Chromatography, University of Pretoria, \\ South Africa
}

\begin{abstract}
Summary. The reproductive organs of the male giraffe differ little in morphology and histology from those of other ungulates. There is some indication that gonadal hypertrophy occurs in late fetal life. Spermatogenesis begins at 3-4 years of age and coincides with a rapid increase of testicular weight and seminiferous tubule diameter. In the fetal testis the main hormone is androstenedione $(2 \cdot 73 \mu \mathrm{g} / \mathrm{g})$ but in adult testes testosterone is predominant $(<10.08 \mu \mathrm{g} / \mathrm{g})$ and $\Delta^{\prime}$ testosterone may also be present.
\end{abstract}

\section{Introduction}

Knowledge of reproduction in male giraffe (Giraffa camelopardalis) amounts to some observations on the testicular artery and characteristics of epididymal spermatozoa (Glover, 1973), a brief account of the anatomy of the male tract (Velhanker, Hukeri, Deshpande \& Sane, 1973), a mention of the reproductive status (Field \& Blankenship, 1973), and a discussion about the absence of seasonal patterns in testicular testosterone levels and other parameters of sexual activity (Hall-Martin, Skinner \& van Dyk, 1975). The purpose of the present report is to describe aspects of development from 270 days after conception (gestation period of 457 days: Skinner \& Hall-Martin, 1975) to maturity in giraffes with particular reference to testicular exocrine and endocrine characteristics.

\section{Materials and Methods}

The reproductive tract was removed from freshly killed male giraffes (including 4 fetuses), in the eastern Transvaal Lowveld, South Africa, and immersed immediately in $10 \%$ formalin. The organs were dissected in the laboratory and the testes, epididymides and bulbo-urethral glands were weighed. Slices of testes were transferred to Bouin's fluid or Zenker-formol solution and processed conventionally for light microscopy. Sections $(6 \mu \mathrm{m})$ of Bouin-fixed tissue were stained with Delafield's haematoxylin and counterstained with chromatrope $2 \mathrm{R}$ or aqueous eosin, and those of Zenkerformol-fixed tissue were placed in potassium dichromate and treated with Sudan black by method 1 of Threadgold (1957). Cross-sections of seminiferous tubules were measured with a Zeiss micrometer eyepiece and the mean of 25 tubules used as the seminiferous tubule diameter.

Fetal and postnatal ages were determined as described by Skinner \& Hall-Martin (1975) and Hall-Martin (1976) respectively. The relative development of fetal and early postnatal gonads was determined from the concentration of interstitial cell nuclei. At $\times 400$ magnification, counts were made of the number of interstitial cell nuclei in 25 squares of an ocular grid for each specimen examined to give the number of nuclei per unit area (one square).

As the giraffes were collected in an endemic foot-and-mouth disease zone only formalin-fixed testicular material could be removed for assay. Samples of testicular tissue $(25 \mathrm{~g})$ were taken and processed individually or pooled (see Table 2), and the extraction methods of Short \& Mann (1966), as modified by Skinner (1967) and detailed by Hall-Martin et al. (1975), were followed. The testicular tissue was homogenized in $2.5 \%$ (w/v) sodium hydroxide solution with $2 \mathrm{mg} \Delta^{\prime}$-methyltestosterone as an internal standard. The homogenate was extracted into ether, evaporated to dryness, redissolved in petroleum ether and extracted again into methanol. After evaporation of the methanol the residue was dissolved in chloroform for liquid chromatography (l.c.) analysis. A $3 \mathrm{~m}$ column (i.d. $3 \mathrm{~mm}$ ) packed with $1 \% \beta \beta$-oxydipropionitrile on Zipax was used with $5 \%$ di-isopropylether in isooctane as the mobile phase. The steroids were detected by u.v. absorption at $254 \mathrm{~nm}$. Testosterone, 
epitestosterone, and androstenedione were not well separated and so were collected, together with the internal standard, as they were eluted from the column for further gas chromatography (g.c.) analysis. $\Delta^{\prime}$ Testosterone, however, was well separated and was measured by mass spectrometry. Extracts derivatized with 2,4-dinitrophenyl hydrazine were separated by the same 1.c. system described above and identified by mass spectrometry. The unseparated fraction from the l.c. column was separated by gas chromatography on $1 \% \mathrm{SP} 2401$ at $250^{\circ} \mathrm{C}$ and $1 \%$ Ov101 at $200^{\circ} \mathrm{C}$. Free hormones and their trimethylsilyl ethers (TMS) (except androstenedione which does not form an ether) were qualitatively and quantitatively analysed; epitestosterone was not quantified. Calibration curves obtained were linear over the region of interest $(1-300 \mu \mathrm{g})$ and tests with authentic mixtures (Fluka AG, Germany) showed that there was no preferential loss on 1.c. or by TMS ether formation. The standard deviation of the calibration curves was less than $5 \%$.

\section{Morphology}

\section{Observations and Comment}

Fetal. The appearance of testes of fetuses and calves (Pl. 1, Fig. 1) and their weights (Table 1) suggest that a decrease occurs in testicular size at birth, and the weight loss is not recovered for several months. This observation is suggestive of gonadal hypertrophy in late pregnancy, as has been reported for the gonads of female fetal giraffes (Kellas, Van Lennep \& Amoroso, 1958; Kayanja \& Blankenship, 1973) and fetal equids of both sexes (Amoroso \& Rowlands, 1951 ; Smuts, 1976).

Table 1. Development of giraffe testes

\begin{tabular}{|c|c|c|c|c|c|}
\hline Specimen & Age & $\begin{array}{l}\text { Body wt } \\
\quad(\mathrm{kg})\end{array}$ & $\begin{array}{c}\text { Testicular wt } \\
(\mathrm{g})\end{array}$ & $\begin{array}{c}\text { Seminiferous } \\
\text { tubule } \\
\text { diam. } \\
(\mu \mathrm{m})\end{array}$ & $\begin{array}{c}\text { No. of } \\
\text { interstitial } \\
\text { cell nuclei/ } \\
\text { square }\end{array}$ \\
\hline \multicolumn{6}{|l|}{ Fetal } \\
\hline$A^{*}$ & 270 days & $16 \cdot 8$ & $2 \cdot 0$ & 一 & - \\
\hline $\mathrm{B}^{*}$ & 336 days & $36 \cdot 3$ & $4 \cdot 2$ & $57 \cdot 0$ & $3 \cdot 2$ \\
\hline $\mathrm{C}^{*}$ & 390 days & $60 \cdot 3$ & $4 \cdot 4$ & $48 \cdot 2$ & $2 \cdot 8$ \\
\hline $\mathrm{D}^{*}$ & 454 days & $101 \cdot 2$ & $9 \cdot 2$ & $56 \cdot 1$ & $3 \cdot 3$ \\
\hline \multicolumn{6}{|l|}{ Neonatal } \\
\hline $\mathrm{E}^{*}$ & $2-3$ days & $100 \cdot 0$ & $6 \cdot 4$ & $57 \cdot 8$ & $2 \cdot 7$ \\
\hline $\mathrm{F}^{*}$ & 6 months & $220 \cdot 0$ & $12 \cdot 6$ & $58 \cdot 7$ & $1 \cdot 8$ \\
\hline $\begin{array}{l}\text { Adult } \\
(\mathrm{N}=14, \text { mean } \pm \text { s.e.m. })\end{array}$ & $>8$ years & $1201 \cdot 4 \pm 31 \cdot 2$ & $536.8 \pm 21.8$ & $196 \cdot 3 \pm 5 \cdot 7$ & $0.6 \pm 0.1$ \\
\hline
\end{tabular}

*Specimens illustrated in Pl. 1, Fig. 1.

Adult. The main features of the adult reproductive tract are those described by Velhanker et al. (1973). The testes, which are descended at birth, are contained in a pendulous scrotum. When fully developed the testes are ovoid, about $10-14 \mathrm{~cm}$ long and 6-8 cm wide (excluding epididymis) at the midpoint, and are suspended with the long axis vertical. The epididymis has no special features and consists of a well demarcated caput, corpus and cauda as in other ruminants. The vas deferens is about $60 \mathrm{~cm}$ long and leads to a prominant ampulla up to $10 \mathrm{~cm}$ in length. Conspicuous paired nonlobulated seminal vesicles open into the urethra. The prostate gland, like that of other ruminants (Trautmann \& Fiebiger, 1957), consists mostly of a lobular pars disseminata which forms a glandular layer in the wall of the pelvic urethra, is wider dorsally than ventrally and has a thick striated urethral muscle along the ventral side. The bulbo-urethral glands are ovoid and are situated in a fibrous capsule on the pelvic part of the urethra, well covered by bulbo-cavernosus muscle. The penis is fibro-elastic and in mature males measures up to $77 \mathrm{~cm}$ when flaccid and has a marked sigmoid flexure. The penis retractor muscles are attached to the distal part of the flexure and are about $13 \mathrm{~cm}$ long. The glans penis is rounded in outline and fiattened laterally; to it is attached a grooved processus urethrae which is about $7.8 \mathrm{~cm}$ long in mature males. 


\section{Histology}

The major features of the cells comprising the seminiferous epithelium and interstitium corresponded closely to published descriptions of these cells in other mammals (Johnson \& Buss, 1967a; Onstad, 1967; Ortavant, Courot \& Hochereau, 1969). Lipid was demonstrated in the Leydig cells by the Sudan black stain.

Seminiferous tubule. In late gestation and for the first year after birth the seminiferous tubules remained solid and underwent no increase in diameter. During this period the tubules contained only the indifferent cells which eventually gave rise to the Sertoli cells and the gonocytes, the number of which increased with age. At the end of this period the testes weighed 24-30 g. Differentiation of the Sertoli cells was complete in a 3-year-old giraffe (Pl. 1, Fig. 2): the characteristics of these cells and the diameter of the fully developed tubule (about $200 \mu \mathrm{m}$ ) were similar to those described for other mammals.

Spermatogonia. These were distinguishable as Types A, B and Intermediate, as in other mammals (Ortavant et al., 1969). Type A spermatogonia (Pl. 1, Fig. 3) were $9 \cdot 6 \pm 0 \cdot 2 \mu \mathrm{m}$ (s.e.m.) in diameter and were found in the two 3-year-old giraffes and all older animals. Type B spermatogonia (Pl. 1, Fig. 3), measuring $4.5 \pm 0.1 \mu \mathrm{m}$ in diameter, could be recognized by the adherence of the chromatin material to the nuclear membrane, as in other mammals, but this material was not as 'beaded' as that found in Rattus norvegicus (Roosen-Runge \& Giesel, 1950) and in the African elephant, Loxodonta africana (Johnson \& Buss, 1967a). Intermediate spermatogonia were $6.4 \pm 0.3 \mu \mathrm{m}$ in diameter.

Spermatocytes. Primary spermatocytes were often difficult to distinguish from the B-type spermatogonia, although their nuclei are smaller, have a less distinct nuclear membrane and stain more darkly. When first recognizable the primary spermatocytes are in the preleptotene stage and are usually close to the basement membrane of the tubule. At leptotene the chromatin filaments are gathered together in a ball with loose ends protruding in all directions and the periphery of the nucleus is almost translucent. During zygotene, the chromosomes are more contracted and the nucleus is darker with an irregular outline. At pachytene the nucleus measures $9.6 \pm 0.2 \mu \mathrm{m}$ in diameter and its chromatin forms a characteristic reticulated pattern. No other stages of meiosis were recognized. Secondary spermatocytes could not be distinguished.

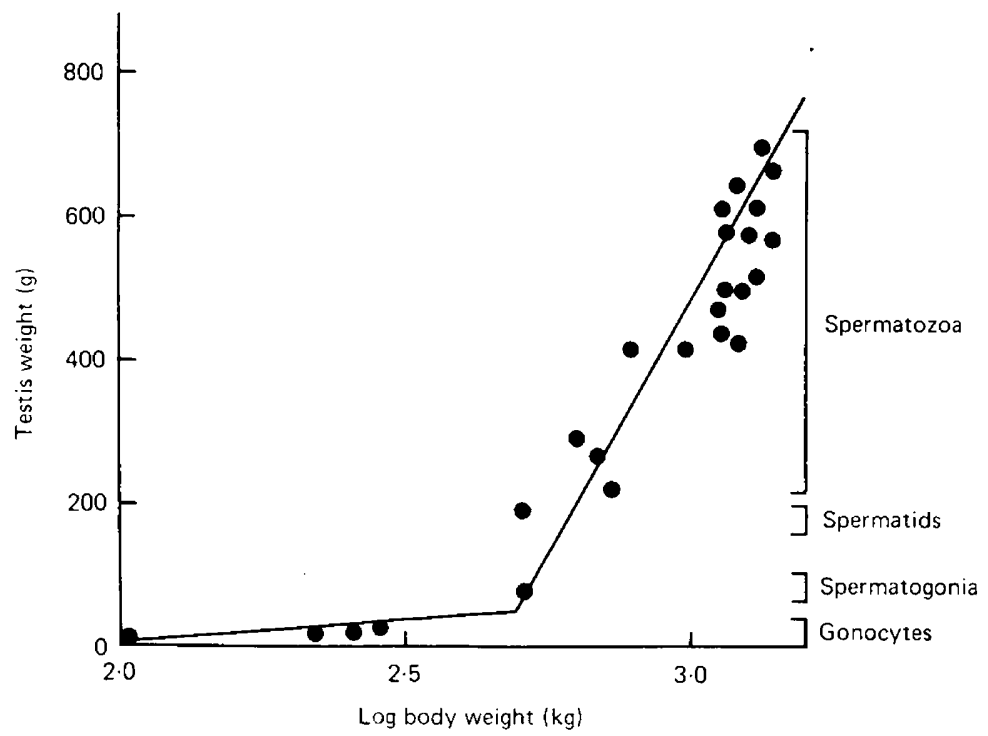

Text-fig. 1. Testicular weight of giraffes plotted against $\log$ body weight to show the two phases of testicular development. The presence of the different germ cell types is also indicated. 
Table 2. Testicular hormones ( $\mu \mathrm{g} / \mathrm{g}$ testis) in giraffes of different ages

\begin{tabular}{|c|c|c|c|c|}
\hline $\begin{array}{c}\text { No. } \\
\text { of animals }\end{array}$ & Age & Testosterone & Androstenedione & $\Delta^{\prime}$ Testosterone \\
\hline \multicolumn{5}{|l|}{ Fetal } \\
\hline $4^{*}$ & $270-454$ days of gestation & $<0.4$ & $2 \cdot 73$ & 0 \\
\hline \multicolumn{5}{|l|}{ Postnatal } \\
\hline $2^{*}$ & 3 days -6 months & 0 & 0 & 0 \\
\hline $3^{*}$ & 8 months -1 year & $<0.4$ & 0.29 & 0 \\
\hline 5 & $3-6$ years & $<0.4$ & 0 & $0-0.4$ \\
\hline 13 & $6-23$ years & $<0.4-10.08$ & $0-1 \cdot 14$ & $0-0.4$ \\
\hline
\end{tabular}

* Testes pooled.

Spermatids. Newly formed spermatids have small $(5 \cdot 3 \pm 0 \cdot 1 \mu \mathrm{m}$ diam.) rounded, lightly stained nuclei bounded by a distinct membrane (Pl. 1, Fig. 3). Their chromatin appeared very granular. The first spermatids appeared in two 3-year-old animals whose testes weighed 80 and $183 \mathrm{~g}$; small numbers of spermatozoa were found in the tubules of the latter specimen. The body weights of these two animals were 513 and $501 \mathrm{~kg}$, respectively (adult body weight $1201.4 \mathrm{~kg}$ : see Table 1). Some of the stages of spermatogenesis are illustrated in Pl. 1, Fig. 3 and the relationship between the time of appearance and testicular weight is given in Text-fig. 1. The various stages of spermatogenesis were similar to those recognized in other mammals (Roosen-Runge \& Giesel, 1950; Monesi, 1964; Onstad, 1967).

The counts made of the interstitial cell nuclei (Table 1) indicate that the population of interstitial (Leydig) cells per unit area is greatest in the fetal testis, is decreased in the postnatal period and reaches a minimum in the adult testis.

\section{Testicular hormones}

The results of measurement of hormones in the formalin-fixed tissues are shown in Table 2 . Testosterone concentration was significantly correlated with age by using correlation analysis (Simpson, Roe \& Lewontin, 1960), but we have no explanation for the great variation in the amounts of testosterone found $(<0 \cdot 4-10 \cdot 08 \mu \mathrm{g} / \mathrm{g})$, or for the failure to detect testosterone in one adult specimen. Androstenedione was confirmed in only five samples, three of which were from adults (Table 2), while trace amounts of $\Delta^{\prime}$ testosterone were found in six of the spermatogenic animals.

As in bulls (Lindner \& Mann, 1960), but unlike rams (Skinner, Booth, Rowson \& Karg, 1968), androstenedione was the dominant testicular androgen until at least 1 year of age. As in other mammals androgenesis preceded spermatogenesis.

\section{Sexual development}

The various features of the reproductive tract measured in this study (see Tables 1 and 3 ) have been recognized as useful features, separately or together, for measuring sexual functions in other wild African ruminants (Skinner, Van Zyl \& Oates, 1974), hippopotamus Hippopotamus amphibius

\section{EXPLANATION OF PLATE 1}

Fig. 1. Testes of fetal and immature giraffes to show differences in size. (A) Fetus, 270 days; (B) fetus, 336 days; (C) fetus, 390 days; (D) fetus, 454 days; (E) neonate, 3 days; (F) juvenile, 6 months.

Fig. 2. Testis of a 3-year-old immature animal. The tubules are greatly enlarged compared with those of a fetus and the lumen (lu) has appeared. Some supporting cells are still present but others are differentiating into Sertoli cells (Se). A dividing gonocyte $(\mathrm{g})$ which would have given rise to spermatogonia is also shown. Bouin, $5 \mu \mathrm{m}, \mathrm{H} \& \mathrm{E}, \times 440$.

Fig. 3. Testis of a 3-year-old pubertal animal. The tubules and lumen (lu) are nearly at maximum diameter and A-type (A) and B-type (B) spermatogonia are located along the basement membrane. Primary spermatocytes (spe) in different phases of meiosis are present and an earlier generation of spermatocytes has given rise to round spermatids (sp). Bouin, $5 \mu \mathrm{m}, \mathrm{H} \& \mathrm{E}, \times 440$. 
PLATE 1
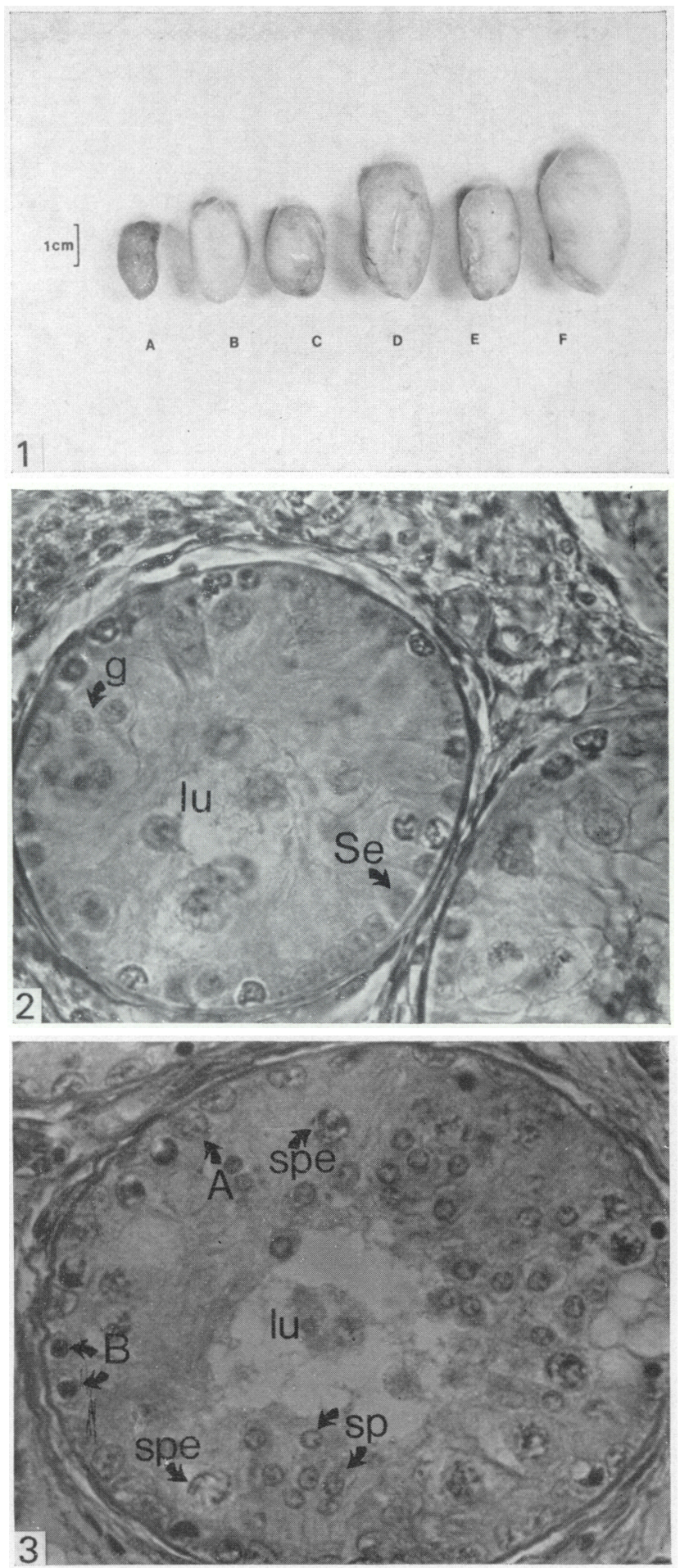

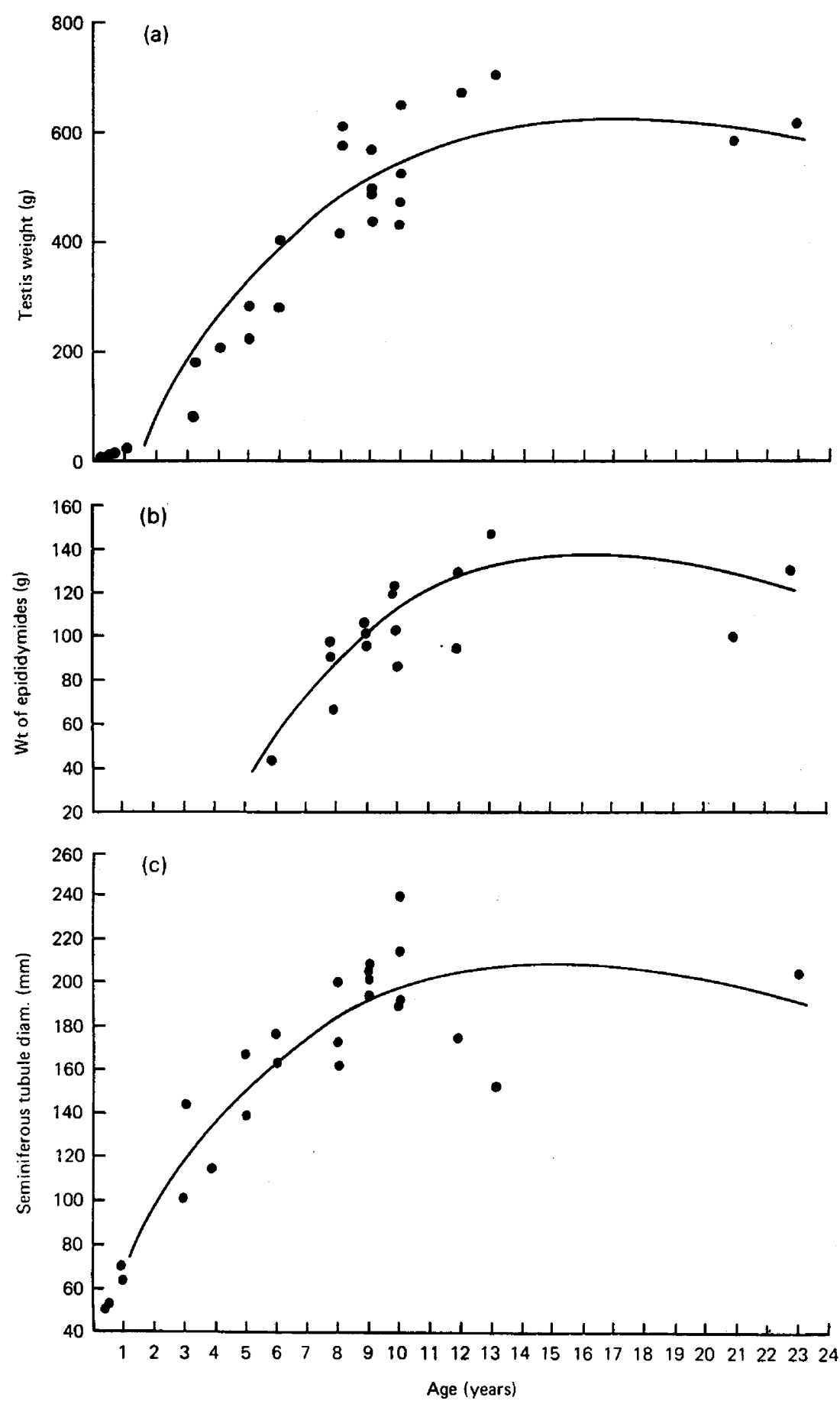

Text-fig. 2. The relationship of (a) testicular weight, (b) epididymal weight and (c) seminiferous tubule diameter to age in giraffes. 
Table 3. Correlation coefficients of various reproductive characteristics of male giraffes

\begin{tabular}{|c|c|c|c|c|c|}
\hline & $\begin{array}{c}\text { Testicular } \\
\text { wt } \\
\text { (g) }\end{array}$ & $\begin{array}{c}\text { Epididymal } \\
\text { wt } \\
\text { (g) }\end{array}$ & $\begin{array}{l}\text { Seminiferous } \\
\text { tubule diam. } \\
\qquad(\mu \mathrm{m})\end{array}$ & $\begin{array}{l}\text { Wt of bulbo- } \\
\text { urethral } \\
\text { glands } \\
(\mathrm{g})\end{array}$ & $\begin{array}{c}\text { Testicular } \\
\text { testosterone } \\
\text { conc. } \\
(\mu \mathrm{g} / \mathrm{g})\end{array}$ \\
\hline Age (years) & $0.818 * * *$ & $0.509^{*}$ & $0 \cdot 738 * * *$ & $0 \cdot 898 * * *$ & $0.683^{*}$ \\
\hline Testicular wt (g) & & $0.862 * * *$ & $0.805^{* * *}$ & $0.832 * * *$ & N.S. \\
\hline Epididymal wt (g) & & & N.S. & N.S. & N.S. \\
\hline Seminiferous tubule diam. $(\mu \mathrm{m})$ & & & & $0 \cdot 774^{* *}$ & N.S. \\
\hline Wt of bulbo-urethral glands (g) & & & & & N.S. \\
\hline
\end{tabular}

Degrees of freedom vary between 6 and 25. N.S., not significant. ${ }^{*} 0.01<P<0.05 ;{ }^{* *} 0.001<P<0.01$; *** $P<0.001$.

(Skinner, Scorer \& Millar, 1975) and elephant (Johnson \& Buss, 1967b; Hanks, 1972). The relationships between testicular and epididymal growth with age, and the expansion of the seminiferous tubules are shown in Text-figs 2(a), 2(b) and 2(c) respectively. Two phases of testicular development are clearly discerned when testicular weight is plotted against the log of body weight (Text-fig. 1), the onset of the second phase being closely associated with the initiation of spermatogenesis and the growth and expansion of the seminiferous tubules, i.e. at about 3-4 years. Some significant correlations between the various reproductive characteristics measured in this study are shown in Table 3. Only three records of the age at first successful breeding in male giraffe could be traced: these were 3 years 9 months (D. Cowie, personal communication), 3 years 6 months (Reuther, 1961) and 2 years 8 months (Crandall, 1964). The mean age at sexual maturity from these records is 3 years 4 months but all refer to captive or tame animals. Because of their relatively small body size and behavioural immaturity at this age (Hall-Martin, 1975) it is unlikely that giraffe in the wild would normally breed as early as this, although they are physiologically capable of doing so.

We thank the owners of the Timbavati and Sandringham Private Nature Reserves for allowing us to collect material for this study; the University of Pretoria and the Council for Scientific and Industrial Research of South Africa for financial support (A.J.H.-M.); Dr H. M. Dott for his assistance; the Nature Conservation Division of the Transvaal for funding aspects of this work through the Mammal Research Institute; and Mr P. Mouton for mass spectra analyses.

\section{References}

Amoroso, E.C. \& Rowlands, I.W. (1951) Hormonal effects in the pregnant mare and foetal foal. $J$. Endocr. 7, 50-53.

Crandall, L.S. (1964) The Management of Wild Mammals In Captivity. University of Chicago Press, Chicago.

Field, C.R. \& Blankenship, L.H. (1973) Nutrition and reproduction of Grant's and Thomson's gazelles, Coke's hartebeest and giraffe in Kenya. $J$. Reprod. Fert., Suppl. 19, 287-301.

Glover, T.D. (1973) Aspects of sperm production in some East African mammals. J. Reprod. Fert. 35, 45-53.

Hall-Martin, A.J. (1975) Studies on the biology and productivity of the giraffe, Giraffa camelopardalis. D.Sc. thesis, University of Pretoria.

Hall-Martin, A.J. (1976) Dentition and age determination of the giraffe, Giraffa camelopardalis. $J$. Zool., Lond. 180, 263-289.

Hall-Martin, A.J., Skinner, J.D. \& Van Dyk, J.M. (1975) Reproduction in the giraffe in relation to some environmental factors. E. Afr. Wildl. J. 13, 237-248.
HANKS, J. (1972) Reproduction of elephant, Loxodonia africana, in the Luangwa Valley, Zambia. $J$. Reprod. Fert. 30, 13-26.

Jounson, O.W. \& Buss, 1.O. (1967a) The testis of the African elephant (Loxodonta africana). I. Histological features. J. Reprod. Fert. 13, 11-21.

Johnson, O.W. \& Buss, I.O. (1967b) The testis of the African elephant (Loxodonta africana). II. Development, puberty and weight. $J$. Reprod. Fert. 13, 23-30.

KAYANJA, F.I.B. \& BlankENSHIP, L.H. (1973) The ovary of the giraffe, Giraffa camelopardalis. J. Reprod. Fert. 34, 305-313.

Kellas, L.M., Van lennep, E.W. \& Amoroso, E.C. (1958) Ovaries of some foetal and pre-pubertal giraffes (Giraffa camelopardalis Linnaeus). Nature, Lond. 181, 487-488.

LindNER, H.R. \& MANN, T. (1960) Relationship between the content of androgenic steroids in the testes and the secretory activity of the seminal vesicles in the bull. $J$. Endocr. 21, 341-360.

MONESI, V. (1964) Ribonucleic acid synthesis during mitosis in the mouse testis. J. Cell Biol. 22, 521-532. 
ONstaD, O. (1967) Studies on Postnatal Testicular Changes, Semen Quality and Anomalies of Reproductive Organs in the Mink. Universiteitsforlaget, Oslo.

Ortavant, R., Courot, M. \& Hochereau, M.T. (1969) Spermatogenesis and morphology of the spermatozoon. In Reproduction in Domestic Animals, 2nd edn, Ch. 10, pp. 251-273. Eds H. H. Cole \& P. T. Cupps. Academic Press, New York.

Reuther, R.T. (1961) Breeding notes on mammals in captivity. J. Mammal. 42, 427-428.

Roosen-Runge, E.C. \& Giesel, L.O. (1950) Quantitative studies on spermatogenesis in the albino rat. Am. J. Anat. 87, 1-30.

SHORT, R.V. \& MANN, T. (1966) The sexual cycle of a seasonally breeding mammal, the roebuck (Capreolus capreolus). J. Reprod. Fert. 12, 337-351.

Simpson, G.G., Roe, A.S. \& Lewontin, R.C. (1960) Quantitative Zoology. Harcourt, Brace and Co., New York.

Skinner, J.D. (1967) Studies on the pubescent male animal. Ph.D. thesis, University of Cambridge.

SkinNer, J.D. \& Hall-Martin, A.J. (1975) A note on foetal growth and development in the giraffe, Giraffa camelopardalis giraffa. J. Zool., Lond. 177, 7376.
SKINNER, J.D., Booth, W.D. Rowson, L.E.A. \& KARG, $H$. (1968) The post-natal development of the reproductive tract of the Suffolk ram and changes in the gonadotrophin content of the pituitary. J. Reprod. Fert. 16, 463-477.

SKINNER, J.D., VAN ZYL, J.H.M. \& OATES, L.G. (1974) The effect of season on the breeding cycle of plains antelope of the western Transvaal Highveld. $J$. sth. Afr. Wildl. Mgmt Ass, 4, 15-24.

Skinner, J.D., Scorer, J.A. \& Millar, R.P. (1975) Observations on the reproductive physiological status of mature herd bulls, bachelor bulls, and young bulls in the hippopotamus, Hippopotamus amphibius amphibius Linnaeus. Gen. Comp. Endocr. 26, 92-95.

SMUTS, G.L. (1976) Reproduction in the zebra mare Equus burchelli antiquorum from the Kruger National Park. Koedoe 19, 89-132.

Threadgold, L.T. (1957) Sudan black and osmic acid as staining agents for testicular interstitial cells. Stain Technol. 32, 267-270.

Trautmann, A. \& Fiebiger, J. (1957) Fundamentals of the Histology of Domestic Animals. Comstock, Ithaca.

Velhanker, D.P., Hukeri, V.B., Deshrande, B.R. \& SANE, C.R. (1973) Biometry of the genitalia and the spermatozoa of the giraffe. Indian vet.J. 50, 789-792.

Received 13 December 1976 